\title{
ДОСТУП ДО ПУБЛІЧНИХ ПОСЛУГ ТА ОРГАНІВ ПУБЛІЧНОї ВЛАДИ: МІЖНАРОДНИЙ ТА АДМІНІСТРАТИВНИЙ ВИМІР
}

\author{
ЖАРОВСЬКА Ірина Мирославівна - доктор юридичних наук, професор, \\ професор кафедри теорії та філософії права, конституційного та міжнародного \\ права Національного університету «Львівська політехніка» \\ РУДАНЕЦЬКА Оксана Стефанівна - кандидат юридичних наук, доцент \\ кафедри права економічного факультету Львівського національного аграрного \\ університету
}

DOI 10.32782/NP.2021.3.3

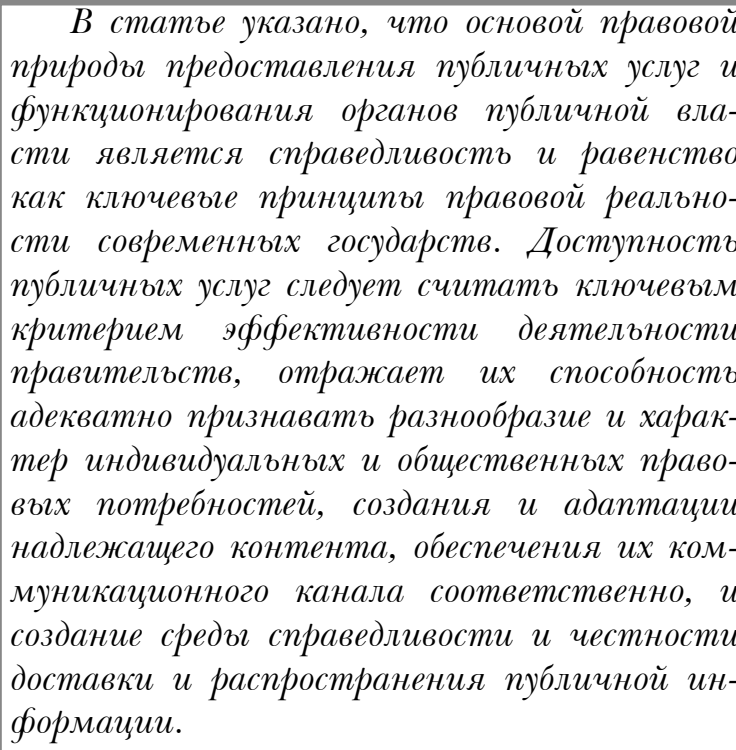

Констатировано, что препятствия для доступа могут иметь различнъие формьи, включая: геограбическое расстояние, неадекватнъле условия для пользователей, требующих специального жилья, недостаточное количество каналов доставки, недостаточная информативность или использования сложного язъка, неудобное время работь или чрезмерные организачионнье проблемы обслуживания населения. Такие барьеры могут снизить соответствия предоставления услуг, спровочировать проблемы с легитимностью всего аппарата публичной власти.

Также опьт ряда иностраннъих государств указъвает, ито экономические затратьл на получение государственной услуги и на ее обслуживание может стать важным препятствием доступа. Финансовая доступ- ность может также повлиять на доверие граждан к справедливости государственных учреждений.

Констатировано, что перевод публичнъхх услуг в электронную форму является залогом их доступности. Платборма электронного правительства должна бътть инклюзивной и обеспечивать равнье возможности доступа всех граждан. В этом смысле электронное правительство должно быть доступнъим. Таким образом, кониепиия доступности в контексте веб-приложений связана с эбббективной доступностью инбормации для всех пользователей, независимо от технологий и платборм, используемъих и сенсорнъхх и функциональных возможностей пользователя. Услуги электронного правительства должнъ способствовать включению людей с особъми потребностями и обеспечивать механизмь, которьие помогут им преодолеть традиционнъие бизические барьерьл.

Ключевъге слова: органъ публичной власти, публичнъие услуги, административнъле услуги, электронное правительство, доступность.

\section{Постановка проблеми}

Вплив основних суспільних благ та послуг у демократичній державі $\epsilon$ вагомим фактором демократичних державно-правових процесів. Суттєвою для окремого громадянина є сфера освіти, охорони здоров'я та правосуддя як простору забезпечення основних прав та свобод людини. 
Питання впровадження електронних публічних послуг є питанням особливого державного значення, оскільки «актуальність цієї теми обумовлена низкою факторів, основними з яких є зростаюче значення інформації для будь-якої сфери життєдіяльності особи, суспільства та держави; входження України в світовий інформаційний простір; поява нових та зростання рівня традиційних загроз в інформаційній сфері, неспроможність влади самостійно їх розв'язати, інформаційною війною Росії проти України; важливістю державного регулюючого впливу на інформаційну сферу та недосконалістю чинного законодавства; необхідністю підвищення рівня обгрунтованості формування та реалізації державної політики розвитку інформаційного суспільства та електронного урядування» [1, с.37].

Актуальність проблематики зумовлена потребою оновлення функціонування державного апарату в межах європейських стандартів 3 метою забезпечення демократизму та правності держави.

\section{Стан дослідження}

Питання оновлення функціонування органів публічної влади ставало предметом аналізу науковців у різних сферах правознавства, зокрема Ю. Бисаги, Д. Бєлова, Н. Бортник, В. Ковальчука, С. Сливки,Н. Сердюк та інших. Однак сфера електронних публічних послуг потребує додаткового аналізу, особливо в контексті забезпечення їх належних правових стандартів, ключовим із яких є доступність.

Метою статті є міжнародний та адміністративний аналіз проблем доступу до публічних послуг та органів публічної влади.

\section{Виклад основних положень}

Первинно слід проаналізувати понятійно-категоріальний апарат задекларованої проблематики. Відповідно до Концепції розвитку системи надання адміністративних послуг органами виконавчої влади, затвердженої розпорядженням Кабінету Міністрів України від 15 лютого 2006 року N 90), сферу публічних послуг становлять послуги, що надаються органами державної влади, органами місцевого самоврядування, підприємствами, установами, організаціями, які перебувають у їх управлінні. Залежно від суб'єкта, що надає публічні послуги, розрізняють державні та муніципальні послуги [2].

Основою правової природи надання публічних послуг та функціонування органів публічної влади є справедливість та рівність як ключові принципи правової реальності сучасних держав. Першу, на думку італійських науковців, слід розділяти на видові особливості. Відповідно до їх поглядів, горизонтальна справедливість - це ступінь, до якої ставляться до осіб у межах класу (наприклад, доходу, статі, здібностей, раси). Вертикальна справедливість - це ступінь участі представників різних класів. Соціальна справедливість відноситься до розподілу впливів за верствами населення, що відрізняються за здібностями та потребами, наприклад дохід, соціальний клас, вік чи здатність бути активним. Просторова справедливість відноситься до просторового розподілу впливів, наприклад, за регіонами чи містами [3, с.2].

Доступність публічних послуг потрібно вважати ключовим критерієм ефективності діяльності урядів, що відображає їх здатність адекватно визнавати різноманітність та характер індивідуальних та громадських правових потреб, створення та адаптації належного контенту, забезпечення їх комунікаційного каналу відповідно, та створення середовища справедливості та чесності доставки та розповсюдження публічної інформації.

Тут слід погодитися 3 Н. Мариняк у тому, що «упродовж останніх років тематика вдосконалення діяльності органів публічної влади за усталеною практикою та особливостями правового регулювання розбивалася на декілька базових блоків - адміністративна реформа, реформа державної служби, електронний уряд, судова реформа. На сучасному етапі змістовний перетин зазначених реформ не дає змоги їх розділяти на окремі, одиничні перетворення. Об'єктом загального реформування має стати державний сектор 3 усіма його 


\section{Адміністративне право}

компонентами - державною службою, фінансами, системою управління та інформаційними ресурсами. При цьому підвищення якості та доступності адміністративних послуг, зниження адміністративних бар'єрів їх надання виступають основними заходами реалізації зазначених перетворень» $[4$, с.1].

Відповідно до міжнародного досвіду для доступу можуть мати різні форми, включаючи: географічну відстань, неадекватні умови для користувачів, які потребують спеціального житла, недостатню кількість каналів доставки (Інтернет, телефон, особистість тощо), недостатню інформативність або використання складної мови (лінгвістичного та технічного характеру), незручний час роботи або надмірні організаційні проблеми обслуговування населення. Такі бар'єри можуть знизити відповідності надання послуг, спровокувати проблеми 3 легітимністю всього апарату публічної влади.

Також досвід низки іноземних держав (у домінанті країн з розвиненою демократією) вказує, що економічні витрати на отримання адміністративної послуги та на їі обслуговування можуть стати важливою перешкодою до доступу. Фінансова доступність може також може вплинути на довіру громадян до справедливості державних установ.

Доступність медичних послуг є одним 3 найважливіших заходів у визначенні якості життя. 3 точки зору соціальної справедливості, кожен повинен мати можливість однаково отримувати доступ до таких послуг. Однак досягнення такої рівності є викликом із різними перешкодами, такими як економічні та географічні питання.

3 огляду на останні демографічні тенденції, що старіють, зростає потреба у розширенні можливостей геопросторового аналізу та моніторингу стану доступності своїх громадян до медичних послуг. Доступність медичної допомоги визначається не тільки географічними відстанями до пунктів обслуговування, але також включає час у дорозі, доступні види транспорту та час відправлення. Наявність доступу до найновішої та точної інформації щодо доступності медичних послуг дозволяе муні- ципальній владі планувати покращення, включаючи розширення інфраструктури охорони здоров'я, ефективний розподіл робочої сили, альтернативні варіанти охорони здоров'я для регіонів 3 обмеженою доступністю, а також переробку маршрутів та розкладів громадського транспорту [5].

Міжнародний моніторинговий звіт [6] вказує, що охорона здоров'я як вагома сфера може першочергово страждати від відсутності фінансової доступності. Хоча більшість країн -членів СС надають універсальні послуги, що передбачені медичним страхуванням, громадянам все одно доведеться платити за деякі послуги або ліки. Ці витрати можуть призвести до того, що деякі громадяни відмовляються або затягують 3 відвідуванням лікаря або лікуванням, тим самим зменшуючи загальний доступ до медичної допомоги. Вказане може призвести до дорожчої госпіталізації на пізньому етапі. Крім того, існуе значна розбіжність у розмірі додаткових (не покритих страхуванням) сум у країнах. Близько 1,5\% кінцевого споживання домогосподарств у Франції, Нідерландах, Туреччині та Великобританії, але 4\% у Чилі, Кореї, Мексиці та Португалії.

Вказане також стосується доступності суду, зокрема юридичного представництва. Надання правової допомоги може сприяти доступу до правосуддя, гарантуючи, що навіть ті, хто не має необхідні фінансові ресурси, усе ще можуть скористатися своїм правом на справедливий суд. Юридична допомога як публічна послуга може мати форму безоплатного або субсидованого юридичного представництва чи юридичного консультування. Для прикладу, Фінляндія, Франція, Нідерланди та Норвегія - тут громадяни отримали правову допомогу понад $10 \%$ справ першої інстанції. У решті країн EC громадяни отримали правову допомогу у $6 \%$ або менше справ першої інстанції.

На європейському рівні доступ до адміністративних послуг та рішень органів публічної влади розглядається в контексті електронного уряду, що розглядається як один із стовпів у побудові Европи, яка сприяє інтеграції та інклюзії громадян та 
сприяє створенню європейського громадянства. План дій електронного уряду на 2016-2020 роки визначає три основні напрямки його місії [7]: (i) модернізація державного управління; (ii) досягнення ринку цифрового Інтернету; та (iii) активніше взаємодіяти з громадянами та підприємствами для надання високоякісних послуг. Можна прийти до висновку, що європейські інститути розглядають електронний уряд як важливу політику щодо сприяння громадянству, стимулювання змін у державних послугах, поширення технологій, сприяння інтеграції систем та процесів та сприяння цифровій інтеграції громадян.

Проте ми не можемо стверджувати, що перевід публічних послуг в електронну форму $\varepsilon$ запорукою їх доступності. Платформа електронного уряду має бути інклюзивною та забезпечувати однакові можливості доступу для всіх громадян. У цьому сенсі електронний уряд має бути доступним. Таким чином, концепція доступності в контексті веб -додатків пов'язана 3 ефективною доступністю інформації для всіх користувачів, незалежно від технологій та платформ, що використовуються, та сенсорних та функціональних можливостей користувача. Послуги електронного уряду мають сприяти включенню людей 3 особливими потребами та забезпечувати механізми, які допоможуть їм подолати традиційні фізичні бар'єри.

\section{Висновок}

Доступність публічних послуг потрібно вважати ключовим критерієм ефективності діяльності урядів, що відображає їх здатність адекватно визнавати різноманітність та характер індивідуальних та громадських правових потреб, створення та адаптації належного контенту, забезпечення їх комунікаційного каналу відповідно, та створення середовища справедливості та чесності доставки та розповсюдження публічною інформацією.

Констатовано, що перепони для доступу можуть мати різні форми, включаючи: географічну відстань, неадекватні умови для користувачів, які потребують спеціального житла, недостатню кількість кана- лів доставки, недостатню інформативність або використання складної мови, незручний час роботи або надмірні організаційні проблеми обслуговування населення. Такі бар'єри можуть знизити відповідності надання послуг, спровокувати проблеми з легітимністю всього апарату публічної влади.

Констатовано, що перевід публічних послуг в електронну форму є запорукою їх доступності. Платформа електронного уряду має бути інклюзивною та забезпечувати однакові можливості доступу для всіх громадян.

\section{Мiтература}

1. Серенок А.О. Довід публічного управління 3 розвитком інформаційного суспільства та електронного урядування країн EC Актуальні проблеми державного управління. 2016. 2(50). С. 36-42.

2. Щодо надання роз'яснення термінів, які застосовуються у Законі України «Про внесення змін до деяких законодавчих актів України щодо відповідальності за корупційні правопорушення»: Аист Міністерства юстиції України 18.12.2009 N 967-0-2-09-22 URL: https://zakon.rada. gov.ua/laws/show/v967-323-09\#Text

3. Accessibility, equity and efficiency Karst T. Geurs, Tomaz Ponce Dentinho and Roberto Patuelli C. 1-8. URL: elgaronline.com

4. Мариняк Н. М. Адміністративноправова характеристика діяльності органів публічної влади у сфері надання адміністративних послуг. Дис. на здоб. наук. ступеня канд. юрид. наук за спец.12.00.07. ПрАТ «Вищий навчальний заклад «Міжрегіональна Академія управління персоналом». Київ, 2021.17 с.

5. Kim Y., Byon Y.J., Yeo H. Correction: Enhancing healthcare accessibility measurements using GIS: A case study in Seoul, Korea. PLOS ONE. 2018. 13(3).

6. Access to public services: Affordability. Government at a Glance 2013, OECD Publishing, Paris. DOI: https://doi. org/10.1787/gov_glance-2013-52-en

7. The e-Government Action Plan 20162020 URL: https://www.europarl.europa.eu/ legislative-train/theme-legal-affairs-juri/file-egovernment-action-plan-2016-2020 


\section{Адміністративне право}

\section{АНОТАЦІЯ}

у статті вказано, що основою правовоі природи надання публічних послуг та функиіонування органів публічної влади є справедливість та рівність як ключові приниипи правової реальності сучасних держав. Доступність публічних послуг потрібно вважати ключовим критерієм ефективності діяльності урядів, що відображає їх здатність адекватно визнавати різноманітність та характер індивідуальних та громадсъких правових потреб, створення та адаптаиій належного контенту, забезпечення їх комунікаційного каналу відповідно, та створення середовища справедливості та чесності доставки та розповсюдження публічною інбормаціею.

Констатовано, щу перепони для доступу можуть мати різні борми, включаючи: геограбічну відстань, неадекватні умови для користувачів, які потребують спеціального житла, недостатню кількість каналів доставки, недостатня інбормативність або використання складної мови, незручний час роботи або надмірні організаційні проблеми обслуговування населення. Такі бар'єри можуть знизити відповідності надання послуг, спровокувати проблеми з легітимністю всъого апарату публічної влади.

Також досвід низки іноземних держав вказує, що економічні витрати на отримання адміністративної послуги та на ї обслуговування може стати важливою перешкодою доступу. Фінансова доступність може також може вплинути на довіру громадян до справедливості державних установ.

Констатовано, що перевід публічних послуг в електронну форму є запорукою їх доступності. Платборма електронного уряду має бути інклюзивною та забезпечувати однакові можливості доступу для всіх громадян. У иъому сенсі електронний уряд має бути доступним. Таким чином, концепція доступності в контексті веб -додатків пов'язана з ебективною доступністю інформациї для всіх користувачів, незалежно від технологій та платфборм, що використовуються, та сенсорних та функціональних можливостей користувача. Послуги електронного уряду мають сприяти включенню людей з особливими потребами та забезпечувати механізми, які допоможуть їм подолати традиційні бізичні бар'єри.

Ключові слова: органи публічної влади, публічні послуги, адміністративні послуги, електронний уряд, доступність.
The article states that the basis of the legal nature of the provision of public services and the functioning of public authorities is justice and equality as key principles of the legal reality of modern states. The availability of public services should be considered a key criterion for the effectiveness of governments, reflecting their ability to adequately recognize the diversity and nature of individual and societal legal needs, create and adapt appropriate content, provide a communication channel accordingly, and create an environment of fairness and fairness.

It was stated that barriers to access can take various forms, including: geographical distance, inadequate conditions for users, need special housing, insufficient delivery channels, insufficient information or use of complex language, inconvenient working hours or excessive organizational problems of public service. Such barriers can reduce the adequacy of service delivery, provoke problems with the legitimacy of the entire public administration.

The experience of a number of foreign countries also indicates that the economic costs of obtaining and servicing administrative services can be an important barrier to access. Financial affordability can also affect citizens' trust in the justice of public institutions.

It is stated that the transfer of public services to electronic form is a guarantee of their availability. The e-government platform must be inclusive and provide equal access for all citizens. In this sense, e-government must be accessible. Thus, the concept of accessibility in the context of web applications is related to the effective availability of information for all users, regardless of the technologies and platforms used, and the sensory and functional capabilities of the user. E-government services should promote the inclusion of people with disabilities and provide mechanisms to help them overcome traditional physical barriers.

Key words: public authorities, public services, administrative services, e-government, accessibility. 